\title{
Learning to teach mathematics specialists in a synchronous online course: a self-study
}

\author{
Margret A. Hjalmarson ${ }^{1}$
}

Published online: 24 October 2015

(C) The Author(s) 2015. This article is published with open access at Springerlink.com

\begin{abstract}
This article uses a self-study research methodology to explore teaching an online course for mathematics specialists. The course included weekly videoconferencing sessions and focused on supporting their development as mathematics coaches working with K-8 teachers to enhance mathematics teaching and learning. The central question for the self-study was about the design of the course and the characteristics of the learning environment that resulted from the design. The study included journal reflections and survey data. Three themes emerged in the analysis of the instructional decision making for the course: student autonomy and engagement, authenticity and practicality, and fostering community.
\end{abstract}

Keywords Mathematics specialists · Online teaching $\cdot$ Self-study $\cdot$ Teacher leaders

\section{Introduction}

If teaching, like engineering and architecture, were treated as a design science, then the practitioners themselves would be building the knowledge base. (Laurillard 2012, p. 5)

There are increasing calls for online and blended course options for working teachers in need of professional development since there are challenges for teachers in coming to a course on campus that may not fit with their work or family schedules. In particular, for practicing teachers seeking advanced licensure or degrees, their needs may be different from prospective teachers who can often more easily attend a face-to-face course. Online courses can remove obstacles such as time and location that can improve access to

Margret A. Hjalmarson

mhjalmar@gmu.edu

1 George Mason University, 4400 University Drive, MSN 1E8, Fairfax, VA 22030, USA 
professional development opportunities. The challenge for teacher education programs is to provide online opportunities using improved technological tools while maintaining the quality of the programs and remaining consistent with the best practices for mathematics teacher education and professional development. Both online and face-to-face environments have constraints and affordances for students and instructors. Decision-making and the design of either requires considering both aspects (Garrison 2015; Stein and Graham 2014).

The mathematics specialist program at George Mason University has been offering courses since Fall 2005. We began offering courses online in order to address increasing requests from teachers for online courses and to widen the geographical radius of access to our courses. The course in this study is the first one offered fully online and represents the transition from face-to-face learning to synchronous online learning. The course included synchronous weekly meetings using videoconferencing as well as the use of other webbased learning tools. I chronicled my learning as an instructor about how to create an online learning environment for teachers based on authentic projects connected to their present and future practice as mathematics specialists as well as emphasizing collaboration and community. A self-study framework for inquiry into practice guided the methodology and frames the conclusions (Chapman 2008; Loughran et al. 2005; Samaras 2011). The investigation is a self-study about my teaching an online course for the first time as well as my teaching of prospective mathematics specialists.

Consistent with the Laurillard quote, my approach to the self-study was to examine design principles I used when creating the course that could inform the design of similar courses by other online instructors (especially instructors designing or teaching a course for the first time). The guiding research question was: what guided my design decisions in facilitating learning in an online, project-based course for mathematics specialist students? Three themes about my role as course designer and teacher emerged from the self-study data analysis: supporting engagement and autonomy; creating authentic and practical learning experiences; and fostering collaboration and community.

\section{Background and literature review}

Recommendations for best practices in teacher education point to using collaborative learning and creating professional learning communities (e.g., Loucks-Horsley et al. 2010; Nickerson and Moriarty 2005; Wenger 1999). In addition, professional development recommendations emphasize the need for practice-based learning experiences grounded in the real work of the teachers (Loucks-Horsley et al. 2010). Also, there is a focus on pedagogical content knowledge driven by the nature of mathematics teaching and learning (Ball et al. 2008). In conjunction with these recommendations, mathematics coaches and mathematics specialists have emerged as school-based professionals who can be needsdriven and work closely with teachers specifically on mathematics teaching and learning topics (Association for Mathematics Teacher Educators 2013; Campbell and Malkus 2011; Fennell et al. 2013; Mudzimiri et al. 2014). There are a limited number of other studies in the area of synchronous online learning in mathematics teacher education (e.g., Francis and Jacobsen 2013; Starling and Lee 2015). Both of these studies investigated mathematics learning but focused on the need for students to be able to discuss the mathematics together in real time. Similarly, in my course, there was a need for real-time discussion of ideas in mathematics teacher leadership. This study brings together the recommendations for 
practice-based mathematics teacher leader development with the emerging context of synchronous online education for teachers.

\section{Online and blended professional development}

Online and blended professional development for teachers is not a new concept (e.g., Dede 2006; Falk and Drayton 2009; Harlen and Doubler 2004; Vrasidas and Glass 2004). Teacher education programs have unique needs for creating online and blended opportunities for teachers, especially in rural areas (Eaton et al. 2015). However, rapidly shifting technologies and increasing online and blended learning opportunities have created an even greater need for research about the design and implementation of online courses for teachers (e.g., Garrison 2015; Vaughan and Lawrence 2013). For online course design, Payne (2004) points to four features supporting online teacher interaction and reflection in a course.

- Providing both individual and group learning opportunities;

- Providing opportunities for feedback and for learner success;

- Designing all assignments, including exams, to be formative, to track and encourage learner progress and reflection;

- Providing maximum learner choice and support; ceding control of learning to the learner(s) (p. 236).

Similarly, other authors point to activity, interaction, collaboration, application, discussion and reflection as core components of online professional development for teachers (e.g., Zellermayer et al. 2004; Barab et al. 2004; Borup et al. 2012). These are similar to the principles we apply to any professional development setting for teachers, but they may be implemented in a different fashion using different types of tools in the online setting. Some of them become more or less challenging in an online setting. For example, some authors have pointed to the opportunity for learners to have more time to reflect before responding in an online, asynchronous activities than face-to-face activities (Laurillard 2012). Hence, the goal in online or hybrid teaching and learning is not necessarily to replicate what happens in a face-to-face context but to find affordances of the online setting that can enhance the teachers' development and provide new means of creating the kinds of interactive, collaborative contexts required for teachers' learning. As a mode for teacher learning and development, the goals of online courses to promote collaboration, formative assessment, and creating teacher ownership of their own learning are consistent with recommendations for teacher professional development generally (Eaton et al. 2015).

\section{Communities of practice}

Related also to teacher development online or face-to-face is the design of communities of practice (Garrison 2015; Wenger 1999; Wenger et al. 2002). For the teachers in the mathematics specialist program, one element of the coursework that is anecdotally important to them is the ability to connect with other mathematics specialists in similar positions at different schools. Mathematics specialists often work in isolation in their dayto-day work given there may be only one position per school or they work between multiple schools. In many settings, there have not been mathematics specialists or coaches so a new mathematics specialist is forging new territory and creating a new role in the school. Thus, the ability to connect with other people with similar practical concerns and day-to-day struggles is a valuable component of the development of a community of 
practice for mathematics specialists. To develop community in an online setting is a challenging proposition that requires some intentionality in design (Barab et al. 2004). While the course had an endpoint, one of my goals is that they will find other mathematics specialists they can rely on for support in a community of practice beyond the end of the course. Consistent with the community of practice framework, "learning is a social process that involves building connections: connections between what is learned and what is important to the learner, connections between what is being learned and those situations in which it is applied, and connections between the learner and other learners with similar goals" (Barab et al. 2004, p. 55).

These recommendations impact this study in two ways. First, the course was designed with consideration to recommendations for best practice in teacher education. Second, given the role of mathematics specialists as teacher leaders and school-based professional development leaders, the course needed to model best practices and provide experience for the teachers in working as teacher developers. It was also imperative to engage the teachers in some of the activities they would likely be doing as mathematics specialists working with teachers. For example, coaching another teacher may be a new experience for mathematics specialists that should be built into the course experience.

\section{Self-study framework}

In order to examine how I used these recommendations to design the course, I adopted a self-study methodological framework to document the course design and implementation during its first semester. Self-study as a teaching research framework emerged from the work of teacher educators to investigate their own practice in order to better understand the practice of educating teachers and to shape teacher education (Loughran 2005; Loughran et al. 2005). It is situated within larger calls for scholarly, reflective practices as teacher educators (Grossman et al. 2009). Other mathematics educators have used self-study to examine their own work as teacher educators as they examine their teaching practice and their own beliefs and assumptions (e.g., Brandenburg 2008; Goodell 2006; Lovin et al. 2012). The work in mathematics education has primarily been completed with prospective teacher courses in face-to-face settings (e.g., Brandenburg 2008; Goodell 2006). However, examples of self-studies of online teaching in a variety of disciplines exist as well (Anderson et al. 2011; Fletcher and Bullock 2014; Ham and Davey 2005; Nicholson et al. 2014).

Self-study as a research framework has a few features that distinguish it from other forms of teacher research: focus on the role of the self as creator and investigator in the teaching environment, the role of critical friends, and the careful documentation followed by reflection about teaching practice (Lunenberg and Samaras 2011; Samaras 2011). Selfstudy requires the instructor to examine and document their practice in order to analyze and understand their role in the teaching environment (Loughran et al. 2005; Samaras 2011). Self-study focuses on examining and making explicit beliefs and assumptions the instructor may have (Brandenburg 2008; Lovin et al. 2012) in order to generate new knowledge that is sharable with the community. In this sense, self-study is motivated by personal interests and motivations as a teacher that are complemented by and contribute to theory and research.

This process of critical reflection is supported and complemented by the use of critical friends who make the work public (Hoban 2004). Therefore, while the research is a study of self within the context of teaching, the research is situated in a collaborative context of feedback from critical friends. In some examples of self-study projects, the instructors are 
teaching a common type of class such as a mathematics teaching methods course (Anderson et al. 2011; Lovin et al. 2012) or using a common tool such as an online social media tool for teachers (Nicholson et al. 2014). In my case, my critical friends and I had a common context, online teaching in teacher education programs. Critical friends in these cases can provide practical, logistical feedback about teaching practice as well as considering the systematic investigation into practice. The ongoing discussion by critical friends in similar situations is important to the development of findings and the progress of the research.

For the online course, self-study was particularly appropriate as I was both exploring new ways to design the course and also adapting pedagogy from my previous teaching experiences in face-to-face courses. I needed to examine beliefs and assumptions about my teaching as a mathematics educator and how they would be manifested in the online teaching environment. Other examples of self-study research include prospective teachers (Lunenberg and Samaras 2011) or other types of novices to a teaching context such as online teaching (Fletcher and Bullock 2014). As an emerging and changing teaching context, online and blended learning settings challenge the instructor to develop new strategies and ways of thinking about teaching and their role as an instructor. A contribution of self-study is making public and analyzing the process of teaching and the exploration of beliefs and assumptions from the perspective of the instructor that exist in the context of teaching. For the current, evolving state of online teacher education initiatives, this making public of the process of teaching is a contribution to understanding how to adapt to changing conditions as teacher educators.

\section{Context}

\section{Course setting}

I investigated a course within a master's degree program for teachers seeking endorsement as K-8 mathematics specialists. For the study, the context is a teacher education course intended to help them learn about models for working with other teachers to improve mathematics teaching and learning at school. The other courses in the program include mathematics courses (e.g., number and operations, algebra, geometry) designed for teachers and education courses in assessment, curriculum, learning and teacher research. The program is consistent with the Association for Mathematics Teacher Education Standards for Elementary Mathematics Specialist Programs (2013) and the National Council for Teachers of Mathematics accreditation standards (2012). At the conclusion of the master's degree program, they receive a state mathematics specialist certification. While there are many ways that mathematics specialists are used in schools, a common theme in their work is supporting teacher professional development at the school and functioning as a mathematics teaching and learning expert in the school (Campbell et al. 2013; Mudzimiri et al. 2014). Some of the teachers are currently working as mathematics coaches, mathematics lead teachers or other teacher leadership roles for mathematics. Others are still working as classroom teachers in public or private, elementary or middle schools. Some mathematics specialists may have a mix of responsibilities including teaching students and leadership responsibilities. For clarity, I will refer to the students in my courses as "teachers" throughout this article. 
The decision to move the course to an online delivery model was not an easy one since we had been successfully offering a face-to-face program for some time. However, a few motivations not unusual for teacher education programs motivated the decision. As the program coordinator, I was receiving increased requests from applicants and current teachers to offer our courses online. Anecdotally, their motivation for wanting an online course is consistent with other rationales. Our teachers are geographically dispersed over a 30-50 mile radius and the urban and suburban region has significant traffic issues that make it difficult to drive to campus. Many of the teachers also have children and families that can make it challenging for them to attend classes in person. The online option also worked better with their school schedules by avoiding conflicts with after school meetings and other late afternoon or evening events for students and parents. Teachers with certain medical conditions were also able to participate in the class because of the online option. Improving the work/life/school balance for teachers was a significant benefit of offering courses online that cannot be neglected when considering how to increase access to courses. In addition, I was personally interested in how an online delivery model could be leveraged to accomplish some activities that were not possible face-to-face. To open our enrollment options as widely as possible and increase access to the program, the program faculty decided to begin offering online courses. Eight months was spent planning the course in this study. I also received support from the university in the form of a summer stipend and assistance from an instructional designer to develop the course. The university as a whole and the college specifically are pursuing more online course and program options, and our college administration is encouraging of online efforts.

\section{My role}

I have been teaching at George Mason University since 2004 and have taught a variety of courses to prospective and practicing teachers. My primary work for the last 5 years has been teaching and coordinating in our K-8 Mathematics Specialist Leader program, which is designed to help teachers learn about mathematics content, pedagogy, learning, assessment, research and professional development. My teaching until this point had been almost exclusively face-to-face. I had some experience using an online learning management system (Blackboard) to support my face-to-face instruction with online grading, document sharing and online assignments but had not taught a class completely online. For this reason, I sought some support from our Office of Distance Education and attended workshops specifically about using Blackboard Collaborate ${ }^{\mathrm{TM}}$ (the web-based, videoconferencing platform within the Blackboard learning management system) to run synchronous, interactive, online class sessions. I also participated in an on-campus faculty group of instructors from multiple departments who were engaged in self-study about e-learning topics supported by our teaching center.

Within Akkerman, Lam and Admiraal's framework for competencies for teachers' professional development (2004), I would describe myself within the college as a "practitioner" leading course and program design for the mathematics specialist program while connecting with other faculty members in my college engaged in online course development by discussing and reflecting about online teaching. Similar to some of the participants in Maor's study of teacher educators (2004), I was comfortable with social constructivist pedagogy as a framework for teacher leader development but still had a significant amount to learn about how the technology could be used to support the kind of interaction and construction of knowledge important to the teachers' learning. Social constructivist pedagogy in this model includes both whole class and small group discussion of content and 
creating scenarios and activities in which the teachers constructed knowledge together drawing on their current experiences and knowledge.

My typical face-to-face class consisted of limited lectures and primarily small-group discussion with whole class sharing. A frequent comment from the teachers in my classes is that they enjoyed connecting with other mathematics specialists and learning from teachers in different contexts. As part of their leadership development, I wanted the teachers to learn about contexts for schools (other than their own) since the job of the mathematics specialist is so varied. Consistent with a social constructivist perspective of learning, I wanted them to build on their own knowledge of mathematics teaching and learning and work in community to further develop their understanding of the role of the mathematics specialist. This connection to community is particularly important for mathematics specialists since they often work as the only (or one of 2-3) mathematics specialists in a building so they need a network of support. When thinking about my teaching, I focused on creating assignments and projects within an environment that focused on the authentic, real work they might encounter in schools. As I have learned more about the evolving role of the mathematics specialists, I have been able to improve assignments and course design to better scaffold their learning in pragmatic and authentic ways.

\section{Course content and structure}

The self-study was situated in a course focused on learning about school change and professional development leadership. The primary objective of the course is to educate the teachers about designing and leading professional development for other teachers in schools as a means of improving mathematics teaching and learning. For the semester under investigation, I focused on two major topic areas that have emerged as important components of mathematics specialists' work in schools: group models for professional development and individual models. In my teaching, I have found mathematics specialists often struggle with the transition from teaching children to leading adults. Part of the challenge in this shift is learning to teach other teachers and the changing role from teacher to teacher leader. For this reason, the two major projects were designed to focus on this role as teacher of teachers and provide them with realistic contexts for engaging in the type of work they would encounter in schools. The two major projects also served to structure the course content and create an overarching focus for the semester.

I designed two projects consistent with these objectives. The first was a lesson study project where the teachers worked in a group to plan, design, implement and reflect on a lesson. The text, Lesson Study Step-by-Step: How Teacher Learning Communities Improve Instruction (Lewis and Hurd 2011), was used to guide the teachers through the lesson study process. Each group created an action plan, submitted a lesson plan, collected a resource list and wrote a final reflection paper about the experience. Each group also presented the results of the lesson study to the class. The second project asked them to go through a coaching cycle (West and Staub 2003) with a teacher where they videotaped or audiotaped their planning and debriefing sessions with the teacher. Observing the teacher was optional since many of them had their own classrooms and I wanted to reduce the scheduling complications. With their lesson study group members, they watched each other's clips and selected one clip to present to the class. Each teacher submitted a 5-min clip from the planning and the debriefing along with a reflection paper as their final project. 


\section{Methodology}

The study included two sections of the course with 11 students in one section and 21 students in the second section. Each class had a mix of secondary (grades 6-12) and elementary teachers and teacher leaders. The class met via videoconferencing technology (with Blackboard Collaborate ${ }^{\mathrm{TM}}$ ) weekly using a similar structure each week for approximately two and a half hours. Using the videoconferencing, each student connected individually to the course from work or home. They could hear audio and could share video if they wanted. ${ }^{1}$ I led a whole class discussion for 10-20 min about the readings, course assignments and other concerns. Then the teachers moved to breakout rooms for 30-45 min for small group discussion about the topics for the week. Finally, they spent the last half of the class working with their group on the lesson study project for the first half of the semester and the coaching project for the remainder of the semester.

All of the students were currently working in schools and represented two types of positions. Many of them were in the classroom working as teachers. Some of the classroom teachers aspired to become mathematics specialists (or other school-based leadership positions outside the classroom) and some were planning to remain in the classroom following graduation. They also represented a range of grade levels from kindergarten teaching through high school. As a group, a mix of middle and elementary school teachers and teacher leaders is typical for the classes in the program and courses often have more elementary teachers than secondary school teachers. Teacher leaders were in elementary or secondary schools in roles such as mathematics or reading specialists, positions in which they worked with remedial groups of students, or held other leadership roles in which they supported teachers with their mathematics instruction. Most of the teacher leaders were from elementary schools, but there are more school-based leadership positions for teacher leaders in elementary schools than in middle schools at this point in time.

The study is situated in a self-study framework that situates inquiry about practice in the context of practice (Brandenburg 2008; Loughran et al. 2005; Samaras 2011). The goal of a self-study project is to understand the researcher's role in the development of the environment (Samaras 2011). Self-study is also a pragmatic perspective in that it often concerns practical questions and the unfolding of phenomena in the context of teaching and learning (Loughran 2005). It is similar to action research or teacher research (Doerr and Tinto 2000) as it is driven by the questions of the teacher and innovations are teacherdesigned and implemented. An added aspect, however, is the focus on the role of the self in the process and the influence I had on the course. Where action research is focused on specific interventions (or actions) that can be taken in a teaching setting, self-study focuses on the role of the teacher in the environment (Samaras and Freese 2006).

To document my role and beliefs, I focused data collection on the documentation of decisions, implementation and the response of the students. Self-study draws on a variety of data sources and analysis methods in order to support investigation into the role of self in the context of practice. A significant part of self-study is the role of critical friends to support the design of the study and provide data analysis support and feedback (Lovin et al. 2012; Lunenberg and Samaras 2011; Samaras 2011). Such critical friends provide an external perspective on the study of self and help shape and triangulate data analysis realistically. I participated in a university self-study group about e-learning during

\footnotetext{
${ }^{1}$ Blackboard Collaborate ${ }^{\mathrm{TM}}$ is similar to Adobe Connect $^{\mathrm{TM}}, \mathrm{WebEx}^{\mathrm{TM}}$ and other online videoconferencing or webconferencing tools that enable audio, video and chat window participation and document sharing. It also allows participants to move into and out of virtual breakout rooms within the same session.
} 
2012-2013, and a subset of those members from the Graduate School of Education worked as a critical friends group who provided me feedback as I was teaching the course and with my data analysis the following semesters. My critical friends group included my counterpart program coordinator in the reading specialist program and a colleague in special education who were both teaching and designing online courses for their programs (WardParsons et al. 2014). We were all novices to self-study and to online teaching.

The qualitative self-study reported here employed two major sources of data: first, my journal reflections from throughout the semester for each class session; second, two anonymous surveys (mid-semester and end-of-semester) conducted with the teachers enrolled in the course sections to understand their perceptions of the course and particularly the video-conferencing sessions each week. Comments on the end-of-semester course evaluations were also reviewed for further information about students' perceptions of the course.

For the journal reflections, each class session, I took notes about my reflections both as class occurred and after class had ended. These reflections served to chronicle my evolution as an online instructor of teachers throughout the semester and decisions I made as the course proceeded. Reflection journals play a significant role as data for self-study by documenting evolution over time and as a textual chronicle of change (Brandenburg 2008; Goodell 2006). I took notes during the class primarily as the teachers were working in their small groups both to keep myself engaged in the process (especially as they were working in small groups) and to document my thinking in situ.

For analysis, I first organized the journal reflections and class notes chronologically and wrote a memo (Maxwell 2005) to synthesize and to summarize my interpretation of major themes month to month. The memo included identifying emergent themes and excerpts from my journals. One significant role of my critical friends was the review of this analysis memo and discussion about how they were interpreting the categories I presented. They did not review my journal entries directly. Since I was interested in the development of the course over time and my role as the educator, I focused on those comments in my reflections that touched on those issues.

For the survey design, they were intended to be open-ended and anonymous. As the instructor of the course, I did not want students to feel intimidated or pressured to complete the surveys and I wanted an honest, critical source of feedback about the course. I asked what aspects of the course they found most beneficial as well as areas for improvement. Table 1 shows the items from the surveys. Knowing the time pressures the teachers had in their lives, I also designed the surveys to be focused and short. The surveys were administered online. I asked them specifically about the weekly videoconferencing sessions and what they liked or disliked about the course in general. On the mid-semester survey, I also asked if they had suggestions for the second half of the semester. Survey item 6 regarding the textbooks on each survey was given because the two books (Lewis and Hurd 2011; West and Staub 2003) were new for the course and were selected specifically as resources to guide each of the projects.

To analyze the surveys, I first qualitatively reviewed them for my initial impressions using open coding. Within questions, there were a range of responses but themes emerged across questions probably due to the open-ended nature of the questions. For example, comments about the online learning environment appeared in what the students liked about the course as well as in the question specifically about Collaborate ${ }^{\mathrm{TM}}$. Then, I entered the descriptive, thematic codes (e.g., logistics, collaboration) and notes into a spreadsheet to capture themes and consistent comment types. I also created a memo summarizing my impressions of the survey responses (Maxwell 2005). Consistent with the focus of the self- 
Table 1 Survey items

Mid-semester survey

1. Which section of the class are you in?

2. What do you like most about this class?

3. What do you like least about this class?

4. What could be done to improve the course during the second half of the semester?

5. What do you think about the Collaborate sessions (weekly online conferencing)?

6. Do you have any feedback about the textbook?

7. Is there anything else you would like us to know?

End-of-semester survey

1. Which section of the class are you in?

2. What do you like most about this class?

3. What do you like least about this class?

4. What could be done to improve the course?

5. What do you think about the Collaborate sessions (weekly online conferencing)?

6. Do you have any feedback about the books? Which one did you like best?

7. Is there anything else you would like us to know?

Table 2 Survey response rates

\begin{tabular}{lllr}
\hline Class section & Total enrollment & $\begin{array}{l}\text { Responses to } \\
\text { mid-semester survey }\end{array}$ & $\begin{array}{l}\text { Responses to } \\
\text { end-of-semester survey }\end{array}$ \\
\hline Section A & 11 & 6 & 4 \\
Section B & 21 & 14 & 9 \\
Total & 32 & 20 & 13 \\
\hline
\end{tabular}

study, I focused on comments about the design of the course and their experience as online learners and as mathematics teacher leaders and specialists. Survey items 2, 3 and 5 (Table 1) with general comments about the course and the Collaborate ${ }^{\mathrm{TM}}$ sessions specifically were the most informative for considering how to structure an online course for mathematics teacher leaders. Table 2 summarizes the survey response rates.

The codes in Table 3 were used to characterize the responses thematically as summaries of the aspects of the course they commented on in the surveys. Quotes from students are embedded within the text about findings where relevant. Despite the relatively small number of responses, there were some relatively consistent types of comments about Collaborate $^{\mathrm{TM}}$ and its ability to allow them to connect with colleagues and interact with each other.

\section{Findings}

As I was designing the course, I had two general goals: collaborative learning for teachers and creating authentic experiences for learning about teacher leadership. These were refined over the semester and the following design considerations emerged as refinements and extensions of the original, overarching goals. In the online setting, structures and processes may need to be put in place for goals that may occur naturally in a face-to-face setting (e.g., getting to know other students). 
Table 3 Descriptive codes for survey responses

\begin{tabular}{|c|c|c|}
\hline Code & Description & Sample response \\
\hline Logistics & $\begin{array}{l}\text { Reasons such as a parking or scheduling } \\
\text { for preferring the online course format }\end{array}$ & $\begin{array}{l}\text { I like that I don't have to drive from work, } \\
\text { to class, and then home. That can make } \\
\text { for a painfully long day. I also like that } \\
\text { many times "class" is over whenever our } \\
\text { groups have accomplished our goals for } \\
\text { the day (mid-semester) }\end{array}$ \\
\hline Structure & $\begin{array}{l}\text { Course structure including both whole } \\
\text { class and small group work time }\end{array}$ & $\begin{array}{l}\text { I don't like the main room [because] it } \\
\text { feels awkward to talk without being able } \\
\text { to sense how others are reacting to what } \\
\text { you say. The small group chat rooms are } \\
\text { fine and feel comfortable (mid-semester) }\end{array}$ \\
\hline Group project & $\begin{array}{l}\text { Challenges with the group project } \\
\text { (e.g., non-participating team members, } \\
\text { difficulty in meeting together) }\end{array}$ & $\begin{array}{l}\text { I did not like completing a group project } \\
\text { online. I think the lesson study was a } \\
\text { valuable project but writing a group } \\
\text { paper is difficult online. I preferred the } \\
\text { coaching project where we worked } \\
\text { independently but had a circle of people } \\
\text { to discuss our work with (end-of- } \\
\text { semester) }\end{array}$ \\
\hline $\begin{array}{l}\text { Communication } \\
\text { and } \\
\text { interactions }\end{array}$ & $\begin{array}{l}\text { Ability to communicate and interact with } \\
\text { classmates online in real-time }\end{array}$ & $\begin{array}{l}\text { I feel more comfortable talking in the } \\
\text { smaller groups rather than on the mic to } \\
\text { the whole class... when we share as a } \\
\text { whole class, talking more in the chat } \\
\text { room (like the last class) is more } \\
\text { comfortable (mid-semester) }\end{array}$ \\
\hline $\begin{array}{l}\text { Comfort } \\
\text { increased }\end{array}$ & $\begin{array}{l}\text { Comfort with online, synchronous format } \\
\text { increased over time }\end{array}$ & $\begin{array}{l}\text { I love using Collaborate! It takes a while to } \\
\text { figure out, but the time it takes to become } \\
\text { familiar with it is well-spent (end-of- } \\
\text { semester) }\end{array}$ \\
\hline $\begin{array}{l}\text { Connect with } \\
\text { colleagues }\end{array}$ & $\begin{array}{l}\text { Reading other people's work, connecting } \\
\text { with other teacher leaders }\end{array}$ & $\begin{array}{l}\text { I like them. I like being able to talk with } \\
\text { other teachers in a less threatening way, } \\
\text { whereas in a class where we meet face to } \\
\text { face I would probably talk to the same } \\
\text { people each week (mid-semester, } \\
\text { thoughts about Collaborate }\end{array}$ \\
\hline
\end{tabular}

The findings are situated in my research question for the study about my role in facilitating learning in an online, project-based course for mathematics specialist students. In examining the data, design considerations emerged that were common themes in creating an online, highly interactive, project-driven course. Three themes emerged in the analysis of my instructional decision making for the course: student autonomy and engagement, authenticity/practicality and fostering community. Consistent with a selfstudy, these themes could be considered as areas for concern or design considerations for an instructor selecting tools and shaping the class structure. Consistent also with Laurilliard's argument that teaching is a design science (2012), I have framed my findings from the self-study with particular emphasis toward the principles and design considerations that could be used to design a similar course. 


\section{Student autonomy and engagement dichotomy}

There was an ongoing dichotomy as the course unfolded between my finding means to engage students in the content of the course and students' autonomy within a virtual environment. Given the multiple and varied kinds of distractions that could emerge when students are in front of computer during class and the lack of physical presence in the virtual setting, it was even more important than in a face-to-face course to create discussion questions and topics along with assignments that would engage students in the course content. For example, in my journal reflection from October 15, I wrote "An overall shift I feel I'm observing for myself when creating the course is a movement toward a taskorientation where I create tasks or to-do lists and they have to make progress through the list." This was balanced by my increasing awareness of students' autonomy and the flexibility inherent in the format. As an example, time in a virtual course became less of a driver in the course than facilitating students' engagement with the projects and discussions more independently.

It became clear very quickly that the students were reluctant to participate in discussions as a whole class (even in the smaller class of 11) especially by talking into the microphone. They would type in the chat window if I asked questions and that was a good means for surveying the class. However, they were active participants in small group activities. Some comments on the survey pointed to some frustration with lack of participation in discussions, but overall the students participated either in small groups or in whole class discussions whether they made comments orally or via the chat window.

Collaborate ${ }^{\mathrm{TM}}$ has a feature for breakout rooms whereby the instructor can easily move students into small groups (in their own virtual room) for discussion or allow students to move themselves to a virtual room. One example of using this feature for engagement and autonomy was when I created three breakout rooms (new teacher, experienced teacher, reluctant teacher) to discuss the different types of strategies and interactions they might have with different types of teachers in their schools and participants selected their own topic areas. In my journals, I noted that I felt like a "lurker" in these rooms as I could move in and out of them to listen to conversation. Without being able to see them, it was challenging at times to know what they were doing if there was silence. For example, one group had decided to spend time re-reading materials for a few minutes and I had to ask why they weren't talking.

Consistent with Laurilliard's recommendations about synchronous online discussions requiring scaffolding and her view that scaffolding and support are more difficult online than face-to-face, the tasks need to be tied to real-world experiences, challenging their thinking and fostering collaborative reasoning (2012) in order to encourage engagement. The questions I created for small group discussion often asked them to create something sharable with the class (e.g., a list of challenges for working with either new, experienced or reluctant teachers) as well as analyzing or going further with topics they had read for the week. During whole class discussions, it was easier in some ways for everyone to participate and share their thoughts because of affordances of the technology. For example, regularly I would ask all of them to type a comment or a question into the chat window. This gave access to everyone's opinion and provided time to consider what to say. I could also easily review what they said as it appeared and then use their responses to move the conversation forward or create small group topics based on their topics.

Balancing giving the students more freedom and flexibility with time with the need for the whole class to move forward together became more explicit in the virtual setting for 
me. However, I felt a lot of freedom as the instructor to not be constrained by a physical space or fixed time for class to focus more on the design of experiences and activities that concern about how particular activities were going to be wrapped up during the class time. At the same time, the students were given tasks and objectives to meet on a general time frame for their projects. Within their groups, they created more detailed timelines and created their own space and time for working. For example, the weekly class session was a check-in point for some groups where they might meet briefly and determine some tasks to do (e.g., finding resources about their lesson study topic) and arrange to meet or communicate later in the week. In my journal reflections I wrote, "It's interesting and new to not be scheduling time for students but rather challenging them to schedule their own time based on their own needs for the lesson study. Deadlines and schedules are set within the groups within broad frameworks established by the class. The class session is then more of a 'check-in' point as the class moves forward?" (reference to Lesson Study project, September 17 journal).

Within the survey responses, when asked what they liked most about the class, many of them mentioned some logistical aspect of the course as a positive. Logistics was used to code responses that mentioned the time flexibility, not having to commute to class, being able to work from home/school, or other issues that made the class possible. For instance, "I appreciate not having to come to campus for the class. I also like that we are given a lot of time to work on our projects. I am getting increasingly comfortable with the online format and enjoy the discussions that we can [have] during the class." This logistical flexibility of not having to come to a particular geographical location at a specific time supported students' autonomy and flexibility. Some of the same students who felt positively about the logistical flexibility also pointed to challenges of communicating online in their responses, so this is a tradeoff that an instructor needs to address. In addition, I attempted to scaffold and facilitate the use of the online communication tools as much as possible to mediate this, but online communication technology may always have challenges.

\section{Authentic and practical work for teachers}

As in other recommendations for teacher professional development both online and face-toface (e.g., Elliott et al. 2009; Loucks-Horsley et al. 2010; Ostashewski et al. 2011), finding authentic and practical assignments for mathematics specialists (learning to be teacher leaders) is just as important as for classroom teachers. Authenticity in this setting means providing opportunities and assignments as close to the real work of mathematics specialists as possible while responding to the practical realities of both the online environment and their school settings. I knew from the start of the class that authenticity would be important; however, some elements of practicality continued to emerge over the semester. This sense of authenticity and practicality emerged in both the major assignments for the course and weekly class interactions. As in one response to what a student liked about the course, "I also love that it is on Leadership. Ideas for how to work with my school. How to become a mathematics resource teacher and show the school that I can be a leader."

One means of accomplishing this was that both major projects were set in the teachers' own schools, and they had a high level of autonomy in building their projects as part of making the work authentic and practical. Class discussions were situated in contexts that asked them to consider the real dilemmas a mathematics specialist might face with teachers and administrators. The two major assignments for the course (the lesson study project and the coaching cycle project) were driven by the two most common forms of teacher professional development the mathematics specialists would need to lead: group-based teacher 
development and individual teacher development. However, practical dilemmas emerged as they encountered constraints in their school settings. For this reason, groups created their own timelines and action plans for accomplishing some tasks related to projects even though there was a common deadline for final materials. Creating timelines and action plans is part of the real work of mathematics specialists as well as encountering the practical challenges of innovation in schools. A few students in the survey mentioned challenges with the group project as one thing they disliked about the course (e.g., scheduling challenges, getting equal participation from group members), but this is part of the work of mathematics leadership and learning to overcome the challenges of group interaction is part of what the course was intended to do.

In the class surveys, comments from the teachers mentioned the value of assignments that were directly applicable to their work as mathematics specialists. In particular, lesson study was a form of professional development many of them had either heard about or participated in before and wanted to learn more about. The text included video clips as examples of a lesson study process as well as templates for lesson planning and reflection (Lewis and Hurd 2011). Before the project started, teachers completed a survey with information about their school and home as well as preferences about group members (e.g., preferring to work with other teachers from the same school or close to their home). I then formed the groups around these preferences and placed middle school teachers and elementary teachers in separate groups. Different group structures served as examples of how aspects of lesson study might work with teachers at the same school or different schools. Some groups shared video of the lesson for review when they were too far apart to make travel to each other's schools feasible. Therefore, while not an ideal lesson study setting (where teachers can observe and reflect on site), they gained a feeling for how many of the practices important to the process (e.g., common planning, observation, collaborative reflection) could be accomplished even if teachers were not at the same school. The experience was then as authentic as possible while also accounting for the practical realities of teachers' working lives and the online course setting.

In my reflections on November 12, following one section's presentations of their lesson study projects, I wrote about the areas in which the lesson study project had met or exceeded my goals:

1. Creating a hands-on application of professional development methods that students were learning in the courses (e.g., applying the Lewis book).

2. Engaging them in a collaborative process with other mathematics specialists focused on student learning and instruction.

3. Using the online meeting capabilities to assemble groups from diverse geographic areas in schools while still having some school-based groups.

4. Engaging teachers in a process of planning, implementation and reflection that applies to multiple situations as mathematics specialists.

Of these outcomes, the groups reflected about students' work and instructions most clearly in one group that explored fraction problems with their students and described students' learning. The groups also described how they had created working plans. Some groups met entirely online (sharing video of one teacher's classroom for reflection by the group). Some groups visited each other's classrooms and some groups met both online and in-person to plan the project. These diverse meeting and organization structures served as a representation of the variety of ways that mathematics specialists can work with teachers to accomplish some of the core ideas of lesson study: collaborative lesson planning and analysis of students' mathematical thinking with implications for instruction. The flexible 
logistics afforded by the online tools made the work more practical to accomplish (e.g., by online document sharing, the ability to share and watch video, and the flexibility in class structure to accommodate their work and family needs).

\section{Challenges in fostering community and collaboration}

One challenge as the instructor was fostering community and collaboration. It was one of my initial goals for the course to encourage collaboration; however, the process of supporting collaboration emerged and it became clear that my role as facilitator of collaboration was critical. While the instructor facilitates collaboration in a face-to-face setting, I needed to consider the tools and structures in an online setting that would encourage collaboration and community more explicitly. Since finding a sense of professional community with other people going through the same transitions is an important aspect of the program, this was an aspect that needed to be preserved in the online setting. Also, my experience as a teacher educator as well as the literature about teacher development pointed to collaborative learning environments as positive for teacher development. This sense of community and interaction was one reason I included weekly videoconferencing meetings rather than only using asynchronous tools (e.g., discussion boards, blogs). The survey results supported this design decision as they mentioned the interactive opportunities as positive aspects for the course. It was challenging negotiating facilitating collaboration in the videoconferencing setting as I needed to both learn about the affordances of the technology and design collaborative activities grounded in applied settings for mathematics specialists.

My goal at the beginning of the course was to support developing community, and I learned more about how to use the technology to facilitate both having the teachers interact with a wide variety of people in the course and creating ongoing small groups projects that would provide consistent points of connection throughout the semester. The technology facilitated these collaborations by making it very easy to move students into different groups all the time using the virtual breakout rooms. Teachers were given more opportunities to interact with different people more than they might have in a face-to-face course. I balanced this movement among groups with a consistent small group that worked on the lesson study and the coaching projects together. As I learned more about how the videoconferencing tools worked, I was better able to use tools like the chat window and blog tools to foster discussion that supported their getting to learn about different perspectives.

As the course progressed, fostering community was closely related to fostering communication. For example, groups needed a means for working together on documents and sharing materials. As an element of the flexibility possible in an online environment that encourages student ownership of their learning, I opened a variety of tools for them to use to share resources but did not prescribe any particular tool. With the lesson study project, for instance, there were particular products they needed to submit to me. For their working documents, groups used a blend of email, online document sharing tools (e.g., Google Docs) or application sharing when working together in Collaborate ${ }^{\mathrm{TM}}$. Some groups used Blackboard tools (e.g., document archiving features or wikis). The videoconferencing tool also included the ability for application sharing so that students could work in an application on their own computer and their group members could see their work (as if they were all sitting around the computer together). Many groups used these particularly in preparing final reports or presentations in Word or PowerPoint. Most groups did not opt to use the video to be able to see each other, but it did seem important to them to be able to take shared notes or exchange documents easily. 


\section{Discussion}

One question guided this self-study and the data analysis: what guided my design decisions in facilitating learning in an online, project-based course for mathematics specialist students? The three design concerns I identified (autonomy and engagement, authenticity and practicality, and fostering community and collaboration) served to guide and to reflect the course design and evolution throughout the semester. As design principles for teaching, they guided my choices as well as helped me to understand how the teachers could interact with the content and each other in the course in the online setting. As recommendations for an instructor, they provide guidance about issues and tensions that come to the forefront in an online setting.

Possibly the most immediate of these tensions for the online setting is autonomy and engagement, since the online setting naturally created more autonomy for students and brought the need to consider engagement to the forefront for me as the instructor. In a faceto-face class, the instructor has physical presence in order to gauge engagement in the course activities. Other authors have described the role of social presence and cognitive presence in online teaching and blended learning (Cleveland-Innes et al. 2007; Garrison 2015). There are fewer means of naturally determining engagement except by reviewing student products and in, my case, virtually moving around to listen to groups as they discussed in Collaborate ${ }^{\mathrm{TM}}$.

Community and collaboration are related to the engagement and autonomy in the sense that the former was needed to support the latter. There were aspects of the course that were very similar to a face-to-face course when fostering collaboration and engagement, even though the technology might change the tools available for my instructional decisions. For example, as in face-to-face classes, some groups finish their discussions earlier than others. Groups sometimes have difficulty interacting with each other because of personality differences or other challenges. However, the interaction was not necessarily difficult because of the technology (e.g., a very successful lesson study group was located over 100 miles apart and completed their work together using video, document and application sharing). Learning to work with other teachers is a significant shift for some teachers entering the mathematics specialist role in schools, and that challenge is the same face-to-face or online. What is needed is to understand how the communication is facilitated or inhibited by the available technology. For mathematics teacher leadership development, learning to work with online learning technology to communicate and to lead is necessary for the their development as these technologies become more ubiquitous throughout schools.

While the course was offered with no face-to-face meetings, there were weekly synchronous meetings. This places the course in a unique position of being neither fully online since some definitions of online learning would require $100 \%$ asynchronous interaction nor face to face (since students were not in the same physical space). Blended learning definitions vary (Vaughan 2014), but a consistently used definition is that it is the "organic integration of thoughtfully selected and complementary face-to-face and online approaches and technologies" (Garrison and Vaughan 2008, p. 148). The sense of blending face-toface and online modalities is echoed by other researchers (Graham 2006). The course integrated considerations for small group work from face-to-face settings with technology tools to support virtual learning. Blended learning is one method for balancing the practical needs that cause students and institutions to find online learning desirable with the need for interactions in a teacher education course as part of teacher leadership development (Eaton et al. 2015; Garrison and Vaughan 2008). The teachers' responses to the online 
environment were largely positive but in some cases they were mixed or negative. Some teachers preferred face-to-face interaction and some prefer the online. The mixed responses recognize how the online can make class more convenient or logistically easier, but also seek face-to-face interaction. For example, regarding the Collaborate ${ }^{\mathrm{TM}}$ sessions "I like the convenience of it, but I find it hinders class at many times." In contrast other students prefer the online setting, "I really like them. I am an introvert and prefer studying by myself but I understand that taking a class is being in a group of people so this format really works out great for me. It also saves me time and money (gas, parking...)." While face-to-face instruction, synchronized in time and place, has been the norm in mathematics teacher education, new opportunities have emerged for encouraging engagement from a wider range of students and the technology represents an opportunity for broadening opportunities to access professional development. Synchronous online learning is one opportunity to reach a balance between the convenience of online for some teachers and the need for synchronous discussion and interaction to support learning and development.

In whole class discussions or group discussions, I still needed to find ways to encourage everyone to participate and contribute. In face-to-face classes, there are always people who are more willing to talk than others. The same is true in the online setting; however, the technology can support more democratic and even participation. For example, replying via the chat feature allowed everyone to answer when they were ready as well as see everyone else's response but some students find typing a response challenging. Blogs in Blackboard were also used to allow for reaction to video clips or other materials. While it is challenging and students need time to get accustomed to talking in the synchronous video environment, there are ways to encourage their participation. I also had, in one case, a relatively large class (21), and getting to know them as individuals was something that required more intentionality on my part. As an introductory assignment, they each posted about their background (including a photo) to Blackboard. This helped me get to know them and their interests in becoming a mathematics specialist and the course. However, this was not enough to know them more individually. I used the two online surveys as a means of getting feedback since I had never taught online before and to provide a means of giving them a voice in the course.

Collaboration and community connected to authenticity and practicality because the work of mathematics specialists is, by necessity and design, collaborative as they work with other teachers and administrators (Campbell et al. 2013; Whitenack and Ellington 2007). Since the work is collaborative, the class needed to be collaborative in order to be a reflection of the authentic work of teachers. As a practical element, including the peer review of the coaching videos allowed all students to receive feedback and share their thinking without needing to take up significant class time. The sharing of those videos via online tools allowed for them to watch each other's videos easily. The online tools made the activity more practical and realistic for the setting.

\section{Conclusion}

This was one self-study about my own decision-making and role as an instructor for an online, synchronous course for mathematics specialists. There may be additional considerations for online professional development not associated with a university course (Barab et al. 2004; Dede 2006). In addition, I have ongoing questions about supporting their discussion and participation in class. The projects were successful at engaging them in 
authentic work for mathematics specialists; however, more projects are needed in subsequent courses. The course was driven by the projects that helped to make the course cohesive as well as creating small communities within the course where students got to know each other better by collaborating together. The ongoing creation of online communities of practice is also in need of additional investigation. Also, this course was one of a series that worked to develop the teachers' skills and abilities as mathematics specialists. A longer term study over multiple semesters would be needed to understand how online learning for teacher leadership development in mathematics played out over time.

This was also my first use of a self-study as a methodological tool for analyzing my own teaching. Returning to the Laurillard quote at the start of this article, if teaching is a design practice and we are the designers, we must engage in systematic analysis and reflection about our own practice, beliefs and principles as teachers. Self-study proved a useful framework for shaping data collection and analysis to understand my class as a case of a first venture into online learning. In particular, self-study methodology encourages careful documentation of the rationales for decision-making and the interactive process of creating and reflecting about teaching. For me, this resulted in principles that emerged and were refined throughout the semester. While other principles or ideas may emerge in later semesters with more experience as an online instructor and research is ongoing with other instructors, self-study allowed me to analyze and document my development as an online instructor. A critical component of self-study for this project was the use of critical friends (Loughran et al. 2005; Samaras 2011) who provided both support and feedback about online teaching (including practical suggestions) and helped shape and refine the research results. The story presented here is designed to describe principles that may apply to online courses more generally, but I found helpful particularly as a novice to online teaching and learning settings especially with practicing mathematics teacher leaders.

In considering synchronous online instruction for mathematics specialists (or mathematics teacher leaders), the study examined issues of how to support leadership development. Similar to considerations raised by others, the course needed to support the students' transition from teachers to teacher leaders (Chval et al. 2010; Felton and Page 2014). Other studies have examined their work in schools and impact on elementary students' learning (Campbell et al. 2013; Campbell and Malkus 2011; Whitenack and Ellington 2007), but this study examines the design of a course to support their leadership development that attempted to model some of the experiences they would have as teacher leaders. The projects and course structure were designed to support both their individual work as coaches (e.g., through the coaching project) and the collaborations they would need to develop (e.g., through the lesson study project) as leaders. The online tools in the course supported both of those endeavors and represented technologies they may encounter themselves as a school-based leaders.

Acknowledgments I would like to thank Anastasia Samaras, Allison Ward-Parsons and Anya Evemnova for their support and review of this paper as my self-study critical friends. Aspects of this study and the online course were supported by the Office of Distance Education and the Center for Teaching and Faculty Excellence at George Mason University. Portions of this work were completed while the author was serving as a Program Officer at the National Science Foundation. Any opinion, findings and conclusions or recommendations expressed in this material are those of the author and do not necessarily reflect the views of the National Science Foundation or George Mason University.

Open Access This article is distributed under the terms of the Creative Commons Attribution 4.0 International License (http://creativecommons.org/licenses/by/4.0/), which permits unrestricted use, distribution, and reproduction in any medium, provided you give appropriate credit to the original author(s) and the source, provide a link to the Creative Commons license, and indicate if changes were made. 


\section{References}

Akkerman, S., Lam, I., \& Admiraal, W. (2004). They understand what it takes-A pioneers' view on teachers' professional development. In C. Vrasidas \& G. V. Glass (Eds.), Online professional development for teachers (pp. 249-264). Greenwich, CT: Information Age Publishing.

Anderson, D., Imdieke, S., \& Standerford, N. S. (2011). Feedback please: Studying self in the online classroom. International Journal of Instruction, 4(1), 3-15.

Association for Mathematics Teacher Educators. (2013). Standards for elementary mathematics specialists: A reference for teacher credentialing and degree programs. San Diego, CA: AMTE.

Ball, D. L., Thames, M. H., \& Phelps, G. (2008). Content knowledge for teaching what makes it special? Journal of Teacher Education, 59(5), 389-407. doi:10.1177/0022487108324554.

Barab, S. A., MaKinster, J. G., \& Scheckler, R. (2004). Designing system dualities: Characterizing an online professional development community. In S. A. Barab, R. Kling, \& J. H. Gray (Eds.), Designing for virtual communities in the service of learning (pp. 53-90). Cambridge: Cambridge University Press.

Borup, J., West, R. E., \& Graham, C. R. (2012). Improving online social presence through asynchronous video. The Internet and Higher Education, 15(3), 195-203. doi:10.1016/j.iheduc.2011.11.001.

Brandenburg, R. (2008). Powerful pedagogy: Self-study of a teacher educator's practice. Netherlands: Springer.

Campbell, P. F., Ellington, A. J., Haver, W., \& Inge, V. (2013). Elementary mathematics specialist's handbook. Reston, VA: National Council of Teachers of Mathematics.

Campbell, P. F., \& Malkus, N. N. (2011). The impact of elementary mathematics coaches on student achievement. Elementary School Journal, 111(3), 430-454.

Chapman, O. (2008). Self-study in mathematics teacher education. Presented at the symposium on the occasion of the 100th anniversary of ICMI, Rome. Retrieved from http://www.unige.ch/math/ EnsMath/Rome2008/WG2/Papers/CHAPMAN.pdf

Chval, K. B., Arbaugh, F., Lannin, J. K., van Garderen, D., Cummings, L., Estapa, A. T., \& Huey, M. E. (2010). The transition from experienced teacher to mathematics coach: Establishing a new identity. Elementary School Journal, 111(1), 191-216.

Cleveland-Innes, M., Garrison, R., \& Kinsel, E. (2007). Role adjustment for learners in an online community of inquiry: Identifying the challenges of incoming online learners. International Journal of Web Based Learning and Teaching Technologies, 2(1), 1-9, 11-16.

Dede, C. (2006). Online professional development for teachers: Emerging models and methods. Cambridge, MA: Harvard Education Press.

Doerr, H. M., \& Tinto, P. P. (2000). Paradigms for teacher-centered classroom-based research. In A. E. Kelly \& R. A. Lesh (Eds.), Handbook of research design in mathematics and science education (pp. 403-428). Mahwah, NJ: Erlbaum.

Eaton, S. E., Dressler, R., \& Gereluk, D. (2015). A review of the literature on rural and remote pre-service teacher preparation with a focus on blended and e-learning models (online submission).

Elliott, R., Kazemi, E., Lesseig, K., Mumme, J., Carroll, C., \& Kelley-Petersen, M. (2009). Conceptualizing the work of leading mathematical tasks in professional development. Journal of Teacher Education, 60(4), 364-379. doi:10.1177/0022487109341150.

Falk, J. K., \& Drayton, B. (2009). Creating and sustaining online professional learning communities. New York: Teachers College Press.

Felton, M. D., \& Page, M. (2014). Preparing teacher leaders. Teaching Children Mathematics, 21(2), 92-99.

Fennell, F., McCord Korbett, B., \& Wray, J. A. (2013). Elementary mathematics leaders. Teaching Children Mathematics, 20(3), 172-180.

Fletcher, T., \& Bullock, S. (2014). A collaborative self-study of teaching about teaching... online. Presented at the American Educational Research Association, Philadelphia, PA.

Francis, K., \& Jacobsen, M. (2013). Synchronous online collaborative professional development for elementary mathematics teachers. International Review of Research in Open and Distance Learning, 14(3). Retrieved from http://search.proquest.com.mutex.gmu.edu/docview/1634343343?accountid= 14541

Garrison, D. R. (2015). Thinking collaboratively: Learning in a community of inquiry. New York, NY: Routledge.

Garrison, D. R., \& Vaughan, N. (2008). Blended learning in higher education: Framework, principles, and guidelines (1st ed.). San Francisco: Jossey-Bass.

Goodell, J. E. (2006). Using critical incident reflections: A self-study as a mathematics teacher educator. Journal of Mathematics Teacher Education, 9(3), 221-248. doi:10.1007/s10857-006-9001-0. 
Graham, C. R. (2006). Blended learning systems: Definition, current trends, and future directions. In C. J. Bonk \& C. R. Graham (Eds.), The handbook of blended learning: Global perspectives, local designs (pp. 3-21). San Francisco, CA: Pfeiffer Publishing.

Grossman, P., Hammerness, K., \& McDonald, M. (2009). Redefining teaching, re-imagining teacher education. Teachers and Teaching, 15(2), 273-289. doi:10.1080/13540600902875340.

Ham, V., \& Davey, R. (2005). Is virtual teaching, real teaching? Learnings from two self-studies. In C. M. Kosnik, C. Beck, A. R. Freese, \& A. P. Samaras (Eds.), Making a difference in teacher education through self-study (pp. 101-116). Dordrecht: Springer.

Harlen, W., \& Doubler, S. J. (2004). Online professional development: Science inquiry in the online environment. In C. Vrasidas \& G. V. Glass (Eds.), Online professional development for teachers (pp. 87-104). Greenwich, CT: Information Age Publishing.

Hoban, G. F. (2004). Using information and communication technologies for the self-study of teaching. In J. Loughran, M. L. Hamilton, V. Kubler LaBoskey, \& T. Russell (Eds.), International handbook of selfstudy of teaching and teacher education practices (pp. 1039-1072). Dordrecht: Kluwer Academic Publishers.

Laurillard, D. (2012). Teaching as a design science: Building pedagogical patterns for learning and technology. New York: Routledge.

Lewis, C. C., \& Hurd, J. (2011). Lesson study step by step: How teacher learning communities improve instruction. Portsmouth, NH: Heinemann.

Loucks-Horsley, S., Stiles, K. E., Mundry, S., Love, N., \& Hewson, P. W. (2010). Designing professional development for teachers of science and mathematics. Thousand Oaks, CA: Corwin Press.

Loughran, J. (2005). Researching teaching about teaching: Self-study of teacher education practices. Studying Teacher Education, 1(1), 5-16. doi:10.1080/17425960500039777.

Loughran, J., Berry, A., \& Tudball, L. (2005). Learning about teaching. In C. M. Kosnik, C. Beck, A. R. Freese, \& A. P. Samaras (Eds.), Making a difference in teacher education through self-study (pp. 203-225). Dordrecht: Springer.

Lovin, L. H., Sanchez, W. B., Leatham, K. R., Chauvot, J. B., Kastberg, S. E., \& Norton, A. H. (2012). Examining beliefs and practices of self and others: Pivotal points for change and growth for mathematics teacher educators. Studying Teacher Education, 8(1), 51-68. doi:10.1080/17425964.2012. 657018 .

Lunenberg, M., \& Samaras, A. P. (2011). Developing a pedagogy for teaching self-study research: Lessons learned across the Atlantic. Teaching and Teacher Education, 27(5), 841-850. doi:10.1016/j.tate.2011. 01.008 .

Maor, D. (2004). Opportunities with e-learning: Changing teachers' pedagogies. In C. Vrasidas \& G. V. Glass (Eds.), Online professional development for teachers (pp. 213-229). Greenwich, CT: Information Age Publishing.

Maxwell, J. A. (2005). Qualitative research design: An interactive approach (2nd ed.). Thousand Oaks, CA: Sage Publications Inc.

Mudzimiri, R., Burroughs, E. A., Luebeck, J., Sutton, J., \& Yopp, D. (2014). A look inside mathematics coaching: Roles, content, and dynamics. Education Policy Analysis Archives, 22(50-57), 1-32. doi:10. 14507/epaa.v22n53.2014.

National Council for Teachers of Mathematics. (2012). NCTM NCATE standards (2012)—Elementary mathematics specialist (advanced preparation). Reston, VA. Retrieved from http://www.nctm.org/ uploadedFiles/Math_Standards/NCTM\%20NCATE\%20Standards\%202012\%20-\%20Elementary\%20 Mathematics\%20Specialist.pdf

Nicholson, J., Kroll, L., Perez, L., \& Lin, B. (2014). How can I remain committed to principled practice and integrate digital technologies into my teaching? Self-studies of four teacher educators' journeys in learning to use Edmodo in their college education courses. Presented at the American Educational Research Association, Philadelphia, PA.

Nickerson, S. D., \& Moriarty, G. (2005). Professional communities in the context of teachers' professional lives: A case of mathematics specialists. Journal of Mathematics Teacher Education, 8(2), 113-140. doi:10.1007/s10857-005-4795-8.

Ostashewski, N., Moisey, S., \& Reid, D. (2011). Applying constructionist principles to online teacher professional development. International Review of Research in Open and Distance Learning, 12(6), $143-156$.

Payne, C. (2004). Design for success: Applying progressive educational principles online. In C. Vrasidas \& G. V. Glass (Eds.), Online professional development for teachers (pp. 231-248). Charlotte, NC: Information Age Publishing.

Samaras, A. P. (2011). Self-study teacher research: Improving your practice through collaborative inquiry. Thousand Oaks, CA: SAGE Publications Inc. 
Samaras, A. P., \& Freese, A. R. (2006). Self-study of teaching practices primer. New York: Peter Lang International Academic Publishers.

Starling, T., \& Lee, H. (2015). Synchronous online discourse in a technology methods course for middle and secondary prospective mathematics teachers. Contemporary Issues in Technology and Teacher Education, 15(2). Retrieved from http://www.citejournal.org/vol15/iss2/mathematics/article2.cfm

Stein, J., \& Graham, C. R. (2014). Essentials for blended learning: A standards-based guide. New York, NY: Routledge.

Vaughan, N. (2014). Student engagement and blended learning: Making the assessment connection. Education Sciences, 4(4), 247-264. doi:10.3390/educsci4040247.

Vaughan, N., \& Lawrence, K. (2013). Investigating the role of mobile devices in a blended pre-service teacher education program. Canadian Journal of Higher Education, 43(3), 56-77.

Vrasidas, C., \& Glass, G. V. (Eds.). (2004). Online professional development for teachers. Greenwich, CT: Information Age Publishing.

Ward-Parsons, A., Evmenova, A., Hjalmarson, M. A., \& Samaras, A. P. (2014). Self-study of online teaching in education: Multiple contexts and strategies for peer interaction online. Philadelphia: Presented at the Annual Meeting of the American Educational Research Association.

Wenger, E. (1999). Communities of practice: Learning, meaning, and identity (1st ed.). Cambridge: Cambridge University Press.

Wenger, E., McDermott, R., \& Snyder, W. M. (2002). Cultivating communities of practice. Boston, MA: Harvard Business School Publishing.

West, L., \& Staub, F. C. (2003). Content-focused coaching: Transforming mathematics lessons. Portsmouth, NH: Heinemann.

Whitenack, J. W., \& Ellington, A. J. (2007). A methodology to explain teachers' emerging roles as K-5 mathematics specialists. Presented at the American Educational Research Association, Chicago.

Zellermayer, M., Mor, N., \& Heilweil, I. (2004). Preparing teachers for e-teaching via e-learning. In C. Y. Charalambous \& G. V. Glass (Eds.), Online professional development for teachers (pp. 197-211). Greenwich: Information Age Publishing. 